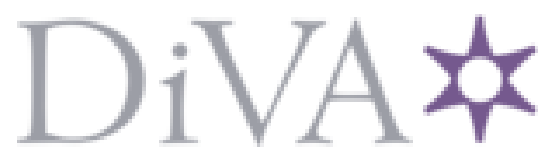

http://www.diva-portal.org

\title{
Postprint
}

This is the accepted version of a paper published in Storytelling: A Critical Journal of Popular Narrative. Theme Issue: Nonfiction Narrative. This paper has been peer-reviewed but does not include the final publisher proof-corrections or journal pagination.

Citation for the original published paper (version of record):

Wennö, E. (2006)

Crossing Over or Crossing the Line?: On the Relevancy of Nonfictional Storytelling.

Storytelling: A Critical Journal of Popular Narrative. Theme Issue: Nonfiction Narrative, 5(2)

Access to the published version may require subscription.

N.B. When citing this work, cite the original published paper.

Permanent link to this version:

http://urn.kb.se/resolve?urn=urn:nbn:se:kau:diva- 17942 


\section{Crossing Over or Crossing the Line? On the Relevancy of Nonfictional Storytelling}

\section{Elisabeth Wennö}

This is how a story begins:

The evening ended quietly, even somewhat gloomily, but then the weather out there did not exactly inspire a festive mood: The wind was tugging at the ship and the cold autumn rain kept beating against the panes.

Besides it was midweek, not the best of times for partying.

So when the M/S Baltica began to rock too much from side to side, the members of the Henry Goy Band stopped playing. The dance-floor was pretty empty and only a handful of people were listening to the Polish-Swedish band's versions of old Elvis and Beatles hits.

In the Tropical Bar, Raymond Shaw didn't have many guests to serve. They were elderly people mostly - quiet and reserved.

The evening drew languidly towards its close. David Jones, aged 63, rose from his table in the bar. He had been watching the few couples dancing, but now he'd had enough and decided to go to bed-the prospects of things perking up seemed pretty bleak.

He went to his cabin on the same floor as the bar, the sixth floor, nearly at the top of the ship. It was shortly after midnight and most of the people that David Jones had been observing in the course of the evening had but a few minutes left to live.

"Ah, you're writing a short story and the guy doesn't know yet, does he!" exclaimed my American colleague as he read the above on my computer screen. There was every reason to assume this even if he was polite enough to refrain from saying that the opening seemed full of clichés and lacked literary qualities. It progresses in the style reminiscent of popular fiction: an opening establishing atmosphere, time, and place, in which characters are introduced one by one to finally reach the enigmatic point that will capture the reader's 
interest. It also proceeds in the kind of metonymic fashion that David Lodge argues is typical of the fictional discourse called "realism" (158-59); a progression based on a cause-effect relationship (in the case above, "bad weathe prevents festive moods"; "the ship's movement prevents the band from playing," and so on), and creating realistic illusion by means of synecdochic details (as above, for example, where "stormy weather at sea" is represented by wind and rain and the type of ship is indicated through dance-floor and bar).

It is, in other words, possible to argue that the quoted passage is an example of the beginning of a fictional "realistic" story of some kind. The only fea63." On the other hand, this is a common marker in fictioner marker "aged mentaries as a technique of creating an illusion of authenticity.

It is not, however, the beginning of a fictional story, but a translation of the beginning of a newspaper report in the Swedish evening tabloid Expressen of 29 September 1994, by journalist Peter Kadhammar. The headline reads, "Life on the Ferry-Death in the Sea," and it features the Estonia disaster. ${ }^{1}$ Apart , "Life on some name changes the translation above is faithful to the original.

It is highly unlikely, of course, that any reader of the article in question should have mistaken it for anything but a newspaper report. The Estonia catastrophe is a deplorable fact, the text is framed by photos from the disaster area, and there are subheadings in the text. But it also is clear that the journalist has chosen to report a historical event ("history") in narrative form ("story"). This type of fictionalization is a frequent phenomenon in the press, especially where dramatic events are concerned. ${ }^{2}$ As Holmberg, among others, has pointed out, events are "best understood if treated as stories" (104). Journalistic ideals of objectivity and factual information are superseded by the desire to move audiences through human-interest stories. The function of narrative journalism is described as follows in a Swedish university textbook on journalism

Journalists also speak of textual enactment and a sense of presence and lived experience. They argue that readers should be able to relate to the evend lived expefar as I know there is only one type of text tions, and that is the narrative text. (Late that has the power to evoke such emo-

Kadhammar's article "Life on the Ferry-Death in the Sea" is a typical example of this type of narrative journalism. It is also an interesting instance of the blurred lines of demarcation between fiction and nonfiction. Nonfictional narratives have been termed natural narrative, a category that includes newspaper reports, while fictional narratives are defined as "artificial [literary] narratives." ${ }^{3}$ The former category is characterized by a truth-claim or verifiability, while the second, as Umberto Eco puts it, "only pretends or verifiability, about the actual universe, or which claims, only pretends to tell the 'truth' universe" (120; elements ances in or utterances, so nonfiction may contain fictive elements or utter80 Storytelling
Ferry-Death in the Sea" is that, by definition, it is a natural narrative, but it behaves like an artificial narrative.

In this essay, I will point to the narrative features that make this text a narrative with literary effects and meanings rather than a narrative type of newspaper report and read it as a fictional text with special reference to the views of Hayden White, Paul Ricoeur, and Tzvetan Todorov on narrativity as a phenomenon. I also will comment on the effect of the "unholy" alliance between the "natural" and the "artificial" that is the result of fictionalization.

My translation from Swedish into English of a newspaper report about a well-known event in Sweden was an experiment designed to make my students aware of the unstable nature of dichotomies such as history/story and fact/fiction. Presented as a text isolated from its paratext and deprived of the textual name-markers that related it to a specific historical event (the names of the ship, the bar, and the passengers), it was accepted as the beginning of a fictional text by the student groups who read it. The fact that the name of the band and its choice of music (Elvis Presley and Beatles hits) remained untampered with made little difference. Historical references of this kind are commonplace in fiction. It is significant, however, that when I revealed that names had been changed and asked again what kind of text they thought it was, the answer was: "the beginning of a novel about the Titanic." My suggestion that the text could be about the 1994 Estonia disaster was rejected on the grounds of its proximity in time. The general view was that the time factor ruled out fictionalization, partly because of human concerns, partly because the event is still "happening" in the form of investigations into cause and accountability, the next-of-kin's struggle for the salvage of the ship, and so on. To this day, it is an ongoing, unfinished event, or drama, in reality and has not yet metamorphosed into an event of the past that can be dramatized and mythologized.

Nevertheless, the Kadhammar article is not the beginning of a novel but an attempt to narrate a specific series of events with a beginning, middle, and end, that is, how it all started, developed, and ended for some of the afflicted. The article presents itself as a representation of reality, but, as we have seen, the representational form is the narrative. It narrates events rather than news.

Nonfictional representations of reality come in many forms. Historians, and by analogy newspaper reporters, do not, as White argues, need to describe what they perceive as true in narrative form. They can choose non-narrative modes, but what they do, the activity as such, is always a kind of narrating or recounting:

While they [for example, de Tocqueville, Burckhart, Huizinga, Braudel] certainly narrated their accounts of the reality they perceived, or thought they perceived, to narrated their accounts of the reality they perceived, or thought they perceived, to
exist within or behind the evidence they had examined, they did not narrativize exist within or behind the evidence they had examined, they did not narrativize
that reality, did not impose upon it the form of a story. And their example permits us to distinguish between a historical discourse that narrates, on the one side, and a discourse that narrativizes, on the other; between a discourse that openly adopts a perspective that looks out on the world and reports it and a discourse that feign to make the world speak itself as a story. (White 274-75; emphasis in original) 
Kadhammar's article is an example of a historical, narrativizing discourse that "feigns to make the world speak itself as a story." The reporter does not pretend to tell the truth (that is, fiction); he believes that he is telling the truth by feigning "to make the world speak itself" (that is, nonfiction). In this respect, the sense of narrativity is created through the technique of relating information and people's experiences in a seemingly unmediated mode of narration. The traditional newspaper reportage is usually a mix of information, commentary, and direct speech, which makes it possible to distinguish between the voices of the interviewer and the interviewees. In contrast, the writer of this article does not adopt the "perspective that looks out on the world and reports it"; he transforms his material into a story. This entails, for instance, shifting focalization (that is, who sees) between external narrative perspectives (not part of the "story") and internal perspectives (part of the "story"), as well as between narrating agents (that is, who says). As in fictional discourse, these shifts are not easily distinguishable. The result is precisely that the events seem to speak themselves, and the role of the author is of secondary importance to the reader. This is a different effect compared with narrative newspaper reports in general, where the voice of the narrating journalist is of importance, as Holmberg points out, "The more familiar, the more credible" (102). There is nothing in Kadhammar's text to indicate that it would gain in credibility if readers knew him better.

If we look at the beginning of "Life on the Ferry-Death in the Sea," we can see that the perspective seems to be external and omniscient until the second sentence of the fourth paragraph where there is a possible shift from external to internal perspective: "They were elderly people mostly-quiet and reserved." It is not clear if this comment is external or internal, that is, a filtering of Raymond Shaw's (my fictive name) opinion. When we get to "the prospects of things perking up seemed pretty bleak," the shift to an internal perspective is, however, definite; David Jones (my fictive name) probably thought this and told Kadhammar, who does not cite it but retells it in a narrativized form: "The evening drew languidly towards its close. David Jones, aged 63 , rose from his table in the bar. He had been watching the few couples dancing, but now he'd had enough and decided to go to bed-the prospects of things perking up seems pretty bleak." The passage illustrates the traditional features of fictional discourse: summary ("The evening drew languidly towards its close"), transition to a scene or action ("rose from his table"), retrospection ("He had been watching"), and internal filtering ("and decided to go to bed"). The article also displays the technique in fiction to create an illusion of eventspace-time coherence in the narrative. While David Jones "dozed," we are told that XX, aged 35, "lingered in the bar," and that YY, aged 45, from X-city was "already asleep." The few occasions on which direct speech is used are there to heighten the dramatic effect rather than to add credibility:

At 00:24 hrs the signalist on the Estonia sent the distress signal: Mayday, mayday, we have a 20 to 30 degrees list and blackout, mayday . .

Ikka Karppala of the Finnish coast guard picked up the signal and heard the sig nalist's next words:

"We are sinking! The engines are out!"

In actual fact, the above passage is a highly condensed and differing version of Estonia's radio contact with the surrounding world. According to the published transcript in Swedish by Stefan Lundberg of the mixed-language radio transmissions (Dagens Nyheter, 14 Oct. 1999) during the fatal night, the conversation lasted considerably longer with lengthy pauses and interruptions. The following (my translation) is an excerpt from the recording that starts when Estonia makes contact with Silja Europa:

Silja Europa: Estonia, Silja Europa, are you calling MAYDAY? Estonia, what is happening? Can you respond?

Estonia (new voice in English): This is Estonia. (Continues in broken Finnish) Who is there? Silja Europa, Estonia.

Silja Europa (in English): Yes, Estonia, this is Silja Europa.

Estonia (in Finnish): Good morning. Do you speak Finnish?

Silja Europa: Yes, I speak Finnish.

Estonia: Well, we have a problem, a heavy list to the right [sic] I think it is 20-30 degrees. Can you assist us and also ask Viking Line for help.

Silja Europa: Yes, Viking Line is behind us and probably received information. What is your position?

Estonia: We have a blackout, we can't get it now, I can't say what it is.

A conversation between Silja Europa and Mariella ensues, until Estonia resumes contact and gives her position. The end of the recording runs as follows:

Silja Europa: Okay, 22 degrees, Roger that, we'll go there.

Estonia: That is 59 latitude and 22 minutes.

Silja Europa: 59.22 minutes longitude.

Estonia: East 21.40.

Silja Europa: East 21.40, okay

Estonia: Really bad, really bad is what it looks like here, yes.

Silja Europa: Yes, and it looks bad. We are on our way and 21.40 it was.

Estonia: ?? (unintelligible) said (unintelligible).

Silja Europa: 48, okay.

At this point, the Estonia's radio transmission ends, and whether or not the Finnish coast guard heard what he heard is anybody's guess. But it is clear that 
Kadhammar's journalistic task of conveying objective information to the public has been superseded by a dramatic impulse.

The Estonia article, then, does not only narrate events but also narrativizes them in White's sense of the term. In "The Value of Narrativity in the Representation of Reality," White attempts to explain the privileged position of the historical narrative in comparison with the annual and the chronicle by arguing that narrativity is more valued because it springs from "a desire to have real events display the coherence, integrity, fullness, and closure of an image of life that is and can only be imaginary" (248). There is every reason to assume that the historian and the journalist share the double task of describing and explaining historical events on one hand and of ascribing significance and meanings to events on the other.

That journalists today have been assigned this double mission is made clear in the research report on the Swedish media coverage of the Estonia disaster published in 1996 (Hadenius, Hedman, and Nowak). The report highlights the problem that news reports of disasters entail: on the one hand, fulfilling the expected function of "recounting and explaining what has happened," and on the other, of "interpreting and ascribing meaning to that which seems beyond comprehension" (113; my translation). The report also emphasizes the obvious, namely that it is impossible for the media to "accurately describe and represent reality." It also is pointed out that evening papers and TV networks are increasingly "accused of making exciting stories of real events, regardless of the catastrophic or tragic nature of the reported events" (15; my translation). Kadhammar's article is cited three times as an example of sensational journalism.

The issue of whether it is in accordance with good press ethics to tell "exciting stories" about tragic events in reality I will leave for now; it is enough to note that Kadhammar's article was not analyzed closely, but is only referred to as an example of dramatic fictionalization, which it certainly is. At the same time, it is clear that the article has assumed the role of "interpreting and ascribing meaning to that which seems beyond comprehension," and that narrativization is the method by which "real events display the coherence, integrity, fullness, and closure of an image of life that is and can only be imaginary," because the world does not appear before us as "a coherence that permits us to see 'the end' in every beginning," as White observes (248)

The very title of the Estonia article permits us to see the end in the beginning, and in the opening quoted above there are textual signals of "the end" in virtually every line. Semantically speaking, words associated with "moving towards the end" ("death") and "nonbeing" are overrepresented in the text: "The evening ended quietly," "gloomily," "did not exactly inspire a festive mood," "the wind was tugging," "the cold autumn rain kept beating," "not the best of times for partying," "rock too much," "stopped playing," "dance-floor was pretty empty," and so on.

Different aspects of the narrative serve to reinforce the impression that the description of events are not only narrated but internally structured as well.
Like White, Ricoeur argues that narrativity is the function that not only accepts the temporality of events but also transcends it through the structure ("plot") that "makes events into a story" (167; emphasis in original), thus offering the possibility to see meaningful coherence in separate events: "By reading the end into the beginning and the beginning into the end, we learn to read time backwards, as the recapitulation of the initial conditions of a course of action in its terminal consequences" (179). Even if we are not already familiar with the events that the narrative recounts, the mode of narration-structurally and discursively - makes it possible to see the end in the beginning and the beginning in the end. Ricoeur calls this nonchronological configuration narrative repetition and suggests that this plot-function not only serves to "establish human action 'in' time, it also establishes it in memory" (179). Narrative repetition per se, or recollection, which, according to Heidegger, constitutes historicity, does not eliminate time, as the concept nonchronological configuration seems to suggest, but adds existential depth (qtd. in White 180).

The existential dimension of "Life on the Ferry-Death in the Sea" is painfully obvious. Before the event occurs (in narratological terms that which upsets equilibrium or order), the event which, as it were, "breaks into" and "breaks off" the time (which Todorov calls "duration-time" as opposed to "event-time," 28), there is a textual emphasis on time ("life") as an ongoing linear continuum of past, present, and future: "[. . .] had been [. . .] Now most of them were asleep in their cabins [...] Next morning they would be [. . .]." It is almost as if Ricoeur had this text in mind when he wonders:

But perhaps the analysis of narrative can also accompany a still more radical movement that would go from historicality to deep temporality following the triple framework [...] the unity of the three "exstases" of time (having-been, coming-forth, and making-present); the primacy of the future over the past, and the present in the unitary constituting of time; and the closure of the future by being-toward-death in its untransferable individuality. (185)

In the article, the journey itself, the narrative "now," is marked as a kind of nontime, a transition in the double sense of time and space, in which what has been and what is anticipated (homecoming) merge: "Saying 'now', says Heidegger, is the discursive [a]rticulation of a making-present which temporalizes itself in a unity with a retentive awaiting" (qtd. in Ricoeur 169; emphasis in original). In its unitary construction of time, the narrative "now" in the article emphasizes the future as primary in relation to what has been and what is. Descriptions of the present situation on board are frequently followed by a future "would": "Tomorrow he would be in Stockholm again," "but only [V.] would make it," "It would save his life," "Next morning they would arrive in Stockholm," and "It would take hours before they were saved." There also is a reminder of "the closure of the future by being-toward-death in its untransferable individuality." Individual, untransferable death is evoked in terms of anonymity and uncontrollability: "Inside the ship people fought to get out. Stairs had turned into walls. Floors had turned into walls. People pushed and 
slid and fell and were knocked unconscious. Only the strongest, and the lucky ones, got out." (The heightening of dramatic intensity through repetitive and-linking of the four verbs in the last sentence also is noteworthy).

In Ricoeur's view, temporality and narrativity are structurally mutually exclusive: temporality is the aspect of existence that reaches language in narrativity, and narrativity is the language structure that has temporality as its ultimate reference (165). The function that White terms narrativity corresponds to Ricoeur's understanding of the action that brings out a pattern in succession, that is the dialectic workings of a narrative's inescapable chronological dimension and its nonchronological dimension (174). The pattern that emerges in Kadhammar's narrative is the existential knowledge of different individuals' shared destined "destination" ("being-toward-death"), versus the difference in destiny as to when the shared destination is reached.

Todorov also regards temporality as a fundamental aspect of a narrative ("the principle of succession"), and like White and Ricoeur, he thinks that narrated events articulated in stories are not only linked through temporality. White's conception of narrativity thus corresponds to Ricoeur's "configurational dimension" (174) and in a structuralist perspective to Todorov's "principle of transformation" (30), which refers to the various ways in which events are related through changes, inasmuch as "a narrative requires the unfolding of an action, change, difference" (28).

The succession of events in our story is built on the principle that Todorov calls "transformation of negation" (30), that is, something transforms into its opposite or contradiction, or, in other words, into something it is not. The overriding transformation in the Estonia story is expressed in the title: "From Life to Death." There also are a number of similar types of movement from a positively charged term to a negatively charged one: from light to dark ("but then everything turned black, the light just disappeared"); from warm and dry to cold and wet ("he was washed into the cold sea"); from sound to silence ("He heard the silence quite clearly and understood that now it was serious"); from order to chaos ("the water rushed in"; "suddenly the suitcase crashed into the cabin door and the table and a chair were also hurled against it"; "a vending machine nearly crushed him, my God, the machine just came flying"; "Stairs had turned into walls. Floors had turned into walls"); from safety to unsafety (from "they were quite safe, there was nothing to worry about" to the discovery that "something was wrong").

According to Todorov, this kind of transformation has a "formative power" in the sense that it forms a narrative sequence in itself. But the text also includes transformations of the category that Todorov sees as having an "evocative power" (34-35). An example of this kind of power to establish atmosphere or provoke thoughts (and here, as elsewhere, I refer to the narrative presentation; not to how I think the situation was experienced by the afflicted) is the change from the state of voluntary nonactivity that characterized the quiet and safe life on board, waiting for homecoming, to the activity and movement breaking out in the face of danger and in the struggle for survival, to a new state of imposed nonatictims and in the stormy and unsafe of imposed nonactivity in death for the victims and in the stormy and unsafe sea for the survivors, waiting anew for homecoming. The text thus sets up structural link between the states life in waiting and death, on the one hand, and homecoming and death, on the other. This perspective gives associations to "death in the sea" as a return, or a homecoming, to the beginning of life, that is, our origin in water and sea.

Another example in the text that evokes similar associations to life and birth Another example in the encription of the monitors in the engine-room, which normally displayed dead, uneventful, scenes from the car deck, but now he saw

that water trickled in ... no, it poured in ... water . .

It was nearly one hour after midnight. Sillaste thought he saw rain water and It was nearly one hour a the car and suddenly found himturned the pumps on. Then he moved to the car came in torrents, the outer portself standing in knee-high water. Yes, it really came in torrents, the outer porthole was closed but the inner one seemed to have opened in some way, water
came rushing in, and now the ship started to heel over.

The analogy with life and birth may seem far-fetched, as water is breaking "in" rather than "out," but the inversion of direction harmonizes with the narrarather than "out," but the inversion of seeing "the beginning in the end."

A simply narrated or narrativized, A story about a historit. The offers the opportunity to use irony as a narrative effect from the know. This reader already knows what the individuals spoken of do not yet know. This
discrepancy is frequently exploited in the narrative, as in the following selection of examples:

It had been a calm journey, and tomorrow he would be back in Stockholm.

They had never visited Estonia and that's why they took time off work for the chance of experiencing something new.

It was worth it [the price of the ticket]. He had never been to Tallinn. Neither had his wife. But she didn't want to come along. Afterwards, at home in Borlänge, she was to wonder why.

V. was lying on his berth in his underwear and soon he and his friend would be fighting for their lives, but only [V.] would make it.

[H.] was seasick. He decided to climb on deck for some fresh air. It would save his life.

[...] and they had a common destination. Next day they would be in Stockholm.

The discrepancy between the apparent and the real situation and between expectations and outcome is emphasized again and again. This kind of irony not expectations and outcome is emphasized again an a f mation, linking difonly affects the reading but also works as a principle of organization, linking different individuals through the focus on the common denominator, the ironic contrast between what happened and between their time on the ship and the contrast between what happened and " between their time on the "fun," "field trip," "conference,"

Wennö

Storytelling 
and "experiencing something new"). It is precisely this contrast that, as I will discuss later, also is used to invite reader identification and to draw attention to a general model of life that goes beyond the specific, historical situation. When all the "characters" have been introduced, a parallel is drawn between the Estonia and a community:

Now most of them were in their cabins, sleeping or waiting for the storm to abate and some were too drunk to worry about the storm and some were working, in the kitchen, in the bar, on the bridge, and if these 1,000 people had something in common it must have been that they were quite safe, there was nothing to worry about, the storm was not that hard and then they had a common destination. Next morning they would be in Stockholm. (36)

In the last paragraph of the article, the analogy is repeated, reinforcing the impression that the narrativizing effort is in the service of meaning-creation rather than news reporting: "Six minutes after M/S Estonia's distress signal the ship disappeared from the radar screens. A small community vanished into the depths. All that remained were some frozen remnants, and it would take hours before they were saved" (38).

The safe community that suddenly and unexpectedly is reduced to "some frozen remnants" does not only echo the classic culture/nature conflict but also reflects the vulnerability and insignificance of humankind in an existence that neither works according to rational principles, nor according to individual expectations or intentions.

As I have shown, Kadhammar's article does not merely report "history" in the form of a narrative or a fictionalized "story"; it is possible to read it as a fictive and literary text, that is, as if it had a different purpose than to convey information in a narrative form. In the perspective of a taxonomy of communicative functions - the informative, the directive, and the presentational (Pettersson 71-72) - Kadhammar's text falls neatly into the category presentational, and as Pettersson claims, in a communicative perspective, a discourse in which the presentational function dominates is literary, whether fictive or nonfictive. Apparently, Kadhammar's intention was not primarily to inform us of reality, nor to make us act (the directive function); instead, he tries to present an image of reality in such a way that we are forced to reflect on and experience that image. In this process, he has made use of narrative irony, dramatizations, and other fictional conventions such as thematic structures in textual elements and series of events. The text is clearly primarily composed and narrated with the purpose of evoking emotions and thoughts, not to give information.

It is possible to read the news article as if its claim to truth is subordinated to another claim, that of relevancy. Although the relevance of a nonfictional narrative is expected to be closely associated with its truth-claim, the fictional narrative's claim to relevancy does not necessarily lie in its credibility in relation to actual reality (true-false utterances), but in its power to make sense of reality. "Life on the Ferry-Death in the Sea" is a nonfictional narrative in the sense that it is directly linked to reality by virtue of a historical event, a number of his- torical individuals, and a paratext, and it speaks the "truth" to a certain extent. But, as we have seen, it also can be read as an interpretation of reality in the same way as we read fiction. The point of such a reading would, in a hermeneutical perspective, be termed structural, or as Henry Cöster puts it: "A narrative does not give substantial information, it gives the pattern by means of which we can see the whole reality" ( 87 ; my translation). The pattern, or the structural, corresponds to the effect of narrativity in White's terminology, as well as to Ricoeur's sponds to the effect of narrativity in White's terminology, as well as to Riconsto

According to the narratological view that Cöster advocates, a narrative is basically a term for "the activity through which we claim relevance" (74; my translation). All stories, whether fictional or nonfictional, however, are not relevant simply by virtue of being narratives. Conversely, a relevant narrative's structural meaning is not in any way given, nor is every nonfictional narrative necessarily true. Whether intentional or not, Kadhammar makes a different claim to relevancy than truth when he chooses to narrate the way he does, and his narrative invites and responds to a mode of reading ("literary") that asks what the text is really about. The answer is not simply a reference to the represented historical really about. The answer is "Estonia disaster," but to a wider part of reality. ${ }^{4}$

The nonfictional referent combined with the fictionalized or narrativized presentation makes the text a hybrid, and in a journalistic news context such texts are problematic as they are "disposable articles" literally and metaphorically speaking. It is highly unlikely that a newspaper reader at the time would have speaking. It is highly unlikely that a newspaper reader at the time would have cle at a later time. My colleague would not have reacted the way he did if he had read the opening in the paper. In this respect, my reading of the text is only of academic interest. Daniel W. Lehman has a point when he argues that it is not meaningful to define fictive and nonfictive texts, because the distinction lies in the different ways that we read fiction and nonfiction. Kadhammar's article was in all likelihood read as nonfiction with a truth-claim on its publication. Thus, it is possible to argue that the article only works as a narrative with relevancy it is possible to argue that the article only works as a narrative with relevancy read out of context and in isolation bisnaled through the composition and narrative strategies. We could further argue that the fictionalization of events is counterproductive because of the frequency of verifiable details (names, ages, motives journeying, and so on) and because of the fact that journalism usually is intimately associated with truth-claims. Instead of working as an interpretation of the incomprehensible, the text might draw attention to fictionalization tion of thethod. This would not be the case, however, if we accept that Lehman is right in his argument that we approach nonfiction differently from fiction.

In the Estonia example, however, we assume that the text is nonfiction, which is why it is equally possible to argue that the presence of the fictional traits and strategies reinforces our belief that it represents the truth. It is quite obvious that the fictionalization is designed to manipulate the reader into a sense of "being there," and there is no reason to question credibility as the situation in which it 
is read is decidedly nonfictional. Fictionalization, or narrativity, serves, in this case, to promote the truth-claim (what actually happened-history) as well as the relevancy-claim (the structural meaning). The unholy fiction-nonfiction alliance is in the service of truth in a double sense: first, we assume that the truth-claim is the text's relevancy and identify with the afflicted on a personal level; second, we are invited to reflect on and experience emotively and cognitively the image of reality that is shaped when history becomes "story" and thus the mediator of another kind of truth than the factual. Paradoxically and unfortunately, the functionality of the article does not only invite a "literary" reading but also works to promote a journalistic illusion of verisimilitude. The narrativity of the representation evokes a pattern that might help us to make sense of life, but in the process, it seduces us into believing that what we read also is a true re-presentation of reality.

There also is an ethical dimension involved, which is related to Kadhammar's use of irony. The ubiquitous narrative irony embedded in the contrast between "what should have been" and "what was" runs the risk of becoming too obtrusive for the simple reason that, in the short-term perspective at least, it is bound to be related to the destiny of historical persons. The knowledge that "they didn't know" makes their deaths more painful and more meaningless to imagine. There is no catharsis effect in this dramatic irony precisely because the reader cannot accept the identification, experience, and meaning that fictionalization is supposed to invite. Against the background of the reader's knowledge of the re-presented reality, the irony appears as a foreground with a questionable relation to the background reality. As Eco points out, early signals of irony constitute the most obvious indications of fictionality (124). The result is that although the ironic foreground invites us to read the narra tive as fiction, the reality of the background insists on its historicity, its nonfiction, its flesh and blood. This discrepancy is probably the reason for the uneasy comments on the article in the report Estonia in the News, and for my students' reluctance to accept it as a story about the Estonia disaster. There are, indeed, events and situations when the tragic irony of life does not need drame tization, especially when nothing is added that we do not already understand.

\section{Karlstad University, Sweden}

\section{ACKNOWLEDGMENT}

A Swedish version of this essay was published in Berättelse i forrvandling, ed. Åke Bervall, Yvonne Leffler, and Conny Mithander (Karlstad, Sweden: Karlstad Universi-
ty Studies, 2000).

\section{NOTES}

1. The M/S Estonia sank off the Finnish coast shortly after midnight on 29 September 1994 on her way from Tallinn to Stockholm. Eight hundred people, mostly
Swedes, lost their lives. ather than convey facts (albeit selective) and to employ the narrative structures and te many examples of fictionalization and personification in the news coverage. Many items and texts seemed to have been designed to evoke emotions and create drama rather than inform the public. Although highly debatable, this tendency indicates the extended function of the media. Reporters today often assume the role of the bard who shapes and interprets reality for us" (273; my translation).

3. Natural narrative is William Labov's sociolinguistic term for oral accounts, which has been applied to written narration and contrasted with artificial narrative by, for instance, Dijk and Searle.

4. See, for example, David Lodge's comparison between George Orwell's "A Hanging" and the newspaper article "Michael Lake Describes What the Executioner Actually Faces" (9-17).

\section{WORKS CITED}

Cöster, Henry. Berättelsen befriar [Narrative Liberation]. Karlstad, Sweden: Karlstad UP, 1980. Dijk, Teun A. "Philosophy of Action and the Theory of Narrative." Poetics 5 (1976): 287-338. Eco, Umberto. Six Walks in the Fictional Woods. Cambridge: Harvard UP, 1995.

Hadenius, Stig, Lowe Hedman, and Kjell Nowak, eds. Estonia i nyheterna [Estonia in the News]. Report 168-3. Stockholm: Nat. Agency for Psychological Defence, 1996.

Holmberg, Claes-Göran. "De sagolika nyheterna" [Fairy-Tale News]. Medietexter och medietolkningar [Media Texts and Media Interpretations]. Ed. Claes-Göran Holmberg and Jan Svensson. Nora: Nya Doxa, 1995. 101-31.

Kadhammar, Peter, "Livet på färjan-Döden i havet" [Life on the Ferry—Death in the Sea]. Expressen 29 Sept. 1994.

Larsson, Sören. Berättande Journalistik [Narrative Journalism]. Stockholm: Natur och Kultur, 1994. Lehman, Daniel W. Matters of Fact: Reading Non-fiction over the Edge. 1997. Columbus: Ohio State UP, 1998.

Lodge, David. The Modes of Modern Writing: Metaphor, Metonymy and the Typology of Modern Writing. London: Arnold, 1977.

Lundberg, Stefan. "Det ser verkligen illa ut här." Dagens Nyheter 14 Oct. 1999: A05

Pettersson, Anders. A Theory of Literary Discourse. Lund, Sweden: Lund UP, 1990

Ricoeur, Paul. "Narrative Time." On Narrative. Ed. W. J. T. Mitchell. Chicago: U of Chicago P, 1981.165-86.

Searle, John. "The Logical Status of Fictional Discourse." New Literary History 6 (1975): 319-32 Todorov, Tzvetan. Genres in Discourse. Cambridge: Cambridge UP, 1990.

White, Hayden. "The Value of Narrativity in the Representation of Reality." Narratology: An Introduction. Ed. Susana Onega and José Ángel García Landa. London: Longman, 1996. 273-95. 